Энергетика. Изв. высш. учеб. заведений и энерг. объединений СНГ. Т. 59, № 5 (2016), с. 452-463

\title{
Effect of the Fill Ventilation Window on Performance of a Natural Draft Cooling Tower Subjected to Cross-Winds
}

\author{
K. V. Dobrego ${ }^{1)}$ \\ ${ }^{1)}$ Belarusian National Technical University (Minsk, Republic of Belarus) \\ (C) Белорусский национальный технический университет, 2016 \\ Belarusian National Technical University, 2016
}

\begin{abstract}
Various aerodynamic design elements and technics (wind deflectors, wind walls, etc.) are utilized for improvement of the thermal efficiency of the natural draft cooling towers, particularly in conditions of cross wind. One of the technical methods, proposed by engineers of Belarus Academy of Sciences, is installation of the ventilation window in the center of the fill. This method is substantiated by the fact that the flow of cooling gas obtains maximum temperature and humidity near the center of the under-fill space of cooling tower and, as a consequence, performs minimal heat exchange. The influence of the fill ventilation window and wind deflectors in the inlet windows of the cooling tower on its thermal performance in condition of cross-wind is investigated in the paper numerically. The cooling tower of the "Woo-Jin" power plant (China) $150 \mathrm{~m}$ of the height and $114 \mathrm{~m}$ of the base diameter was taken as a prototype. The analogy (equivalence) between the heat and mass transfer was taken into consideration, which enabled us to consider single-phase flow and perform complicated 3D simulation by using modern personal computers. Heat transfer coefficient for the fill and its hydrodynamic resistance were defined by using actual data on total flow rate in the cooling tower. The numerical model and computational methods were tested and verified in numerous previous works. The non-linear dependence of the thermal performance of the cooling tower on wind velocity (with the minimum in vicinity of $U_{c r} \sim 8 \mathrm{~m} / \mathrm{s}$ for the simulated system) was demonstrated. Calculations show that in the condition of the average wind speed the fill ventilation window doesn't improve, but slightly decrease (by 3-7 \%) performance of the cooling tower. Situation changes in the condition of strong winds $U_{c w}>12 \mathrm{~m} / \mathrm{s}$, which are not typical for Belarus. Utilization of airflow deflectors at the inlet windows of cooling tower, conversely, increases thermal performance of the cooling tower on 10-12\% for the wide range of winds exceeding $2 \mathrm{~m} / \mathrm{s}$. Results of the investigation may be helpful for optimal design of natural draft and perspective "hybrid" cooling towers.
\end{abstract}

Keywords: cooling tower, numerical simulation, thermal efficiency, cross wind

For citation: Dobrego K. V. (2016) Effect of the Fill Ventilation Window on Performance of a Natural Draft Cooling Tower Subjected to Cross-Winds. Energetika. Proc. CIS Higher Educ. Inst. and Power Eng. Assoc. 59 (5), 452-463 (in Russian)

\section{Адрес для переписки}

Добрего Кирилл Викторович

Белорусский национальный технический университет

просп. Независимости, 65/2,

220013, г. Минск, Республика Беларусь

Тел.: +375 17 292-42-32

ef@bntu.by
Address for correspondence Dobrego Kirill V.

Belarusian National Technical University 65/2 Nezavisimosty Ave., 220013, Minsk, Republic of Belarus Tel.: +375 17 292-42-32 ef@bntu.by 


\title{
Влияние вентиляционного отверстия в оросителе на тепловую работу башенной испарительной градирни в условиях ветра
}

\author{
К. В. Добрего ${ }^{1)}$ \\ ${ }^{1)}$ Белорусский национальный технический университет (Минск, Республика Беларусь)
}

Реферат. Для улучшения тепловой работы башенных испарительных градирен, особенно в условиях ветровых нагрузок, могут использоваться разнообразные аэродинамические элементы и конструктивные решения (дефлекторы, ветроперегородки и т. п.). Одним из предложений, впервые сформулированных сотрудниками Национальной академии наук Беларуси, было сооружение центрального вентиляционного отверстия в оросителе градирни. Данное конструкционное решение обосновывалось тем, что паровоздушный поток вблизи центра подоросительного пространства градирни имеет максимум температуры и влагонасыщенности и вследствие этого слабо участвует в теплообмене. В статье численно исследуется влияние центрального вентиляционного отверстия в оросителе совместно с ветронаправляющими дефлекторами во входном окне градирни на ее тепловую работу в условиях ветра. В качестве прототипа взята градирня ТЭС «Ву-Джин», Китай, высотой 150 м и диаметром основания 114 м. При расчетах используется аналогия тепло- и массопереноса, что позволяет моделировать аэродинамику однофазного потока и выполнять детальные трехмерные расчеты на современных персональных вычислительных машинах Коэффициент теплоотдачи оросителя и его гидродинамическое сопротивление устанавливаются в соответствии с экспериментальными данными по общему расходу воздуха в градирне. Численная модель протестирована и верифицирована в ряде предыдущих исследований. Продемонстрирована нелинейная зависимость тепловой производительности БИГ от скорости ветра с минимумом при $U_{c r} \sim 8 \mathrm{~m} / \mathrm{c}$ для моделируемой системы. Расчет показал, что при средних скоростях ветра устройство центрального отверстия не увеличивает, а наоборот, несколько уменьшает (на 3-7 \%) эффективность работы градирни. Ситуация изменяется при очень сильных ветрах, превышающих 12 м/с, не характерных для условий Беларуси. Использование ветронаправляющих дефлекторов во входном окне градирни, напротив, увеличивает производительность градирни на 10-12 \% в широком диапазоне скоростей ветра, превышающих 2 м/с. Результаты исследования могут быть полезны для оптимизации конструкции градирен, в том числе и перспективных градирен гибридного типа.

Ключевые слова: градирня, математическое моделирование, тепловая эффективность, ветровой поток

Для цитирования: Добрего, К. В. Влияние вентиляционного отверстия в оросителе на тепловую работу башенной испарительной градирни в условиях ветра / К. В. Добрего // Энергетика. Изв. высш. учеб. заведений и энерг. объединений СНГ. 2016. Т. 59, № 5. С. 452-463

Natural draft cooling tower (NDCT) is the important element of the recirculation water cooling system for Condensation Power Plants and Nuclear Power Plants. Both processes of heat and mass transfer (latent heat of evaporation) play essential role for water cooling. Hot water is sprayed over the fill - the highly porous system with expanded surface area, - and flowing down it exchanges heat with opposite gas flow. Meanwhile some fraction of water evaporates and humidity of the gaseous flow approaches $100 \%$. Latent heat of evaporation reduces internal energy (and temperature) of the water. Following that, water drips down to the pool and directed back to condenser (Fig. 1). Total flow rate of the water may be as much as 100 thousand tones per hour at modern power plants and up to $2 \%$ of that may be evaporated and released to atmosphere. 


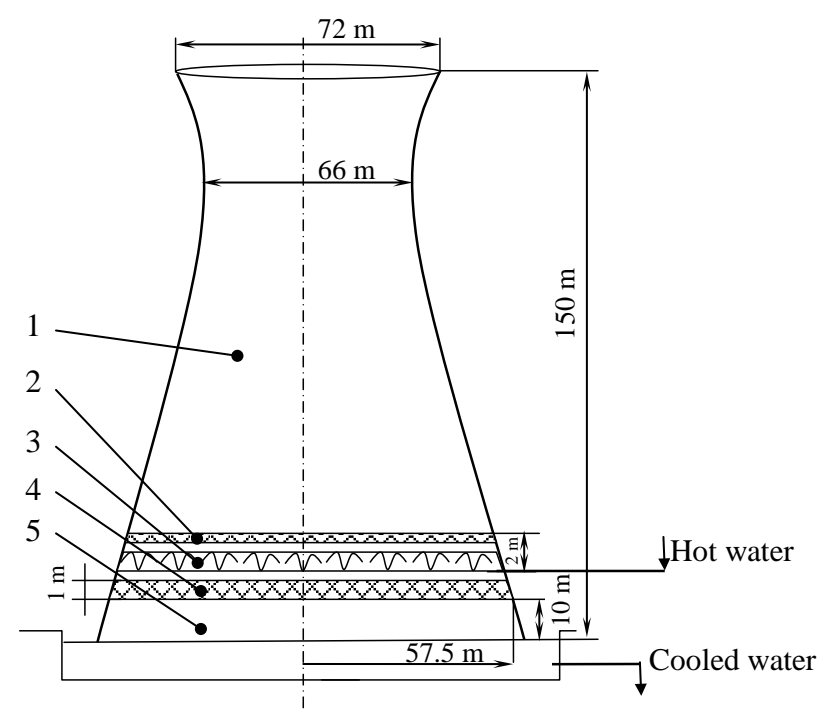

Fig. 1. Natural draft cooling tower scheme: 1 - overshower zone; 2 - drift eliminators; 3 - sprinklers; 4 - fill; 5 - rain zone

Convection in NDCT is defined with internal heat and mass transfer processes as well as with external meteorological conditions: wind speed, temperature, humidity. The effect of the wind is of complicated nature. The total air flow rate and NDCT efficiency is insignificantly effected by weak winds, $U_{c w} \leq 1-2 \mathrm{~m} / \mathrm{s}$. With wind speed growth the total air flow rate decreases due to throttling of the NDCT outflow face with vortexes and throughout flows in the rain zone. Decrease of the NDCT performance continues until the wind speed reaches its "critical" value $U_{c r}$ (within the range from 4 to $10 \mathrm{~m} / \mathrm{s}$ ) and with the further growth of the wind velocity NDCT performance grows.

Numerous papers dedicated to investigation of the wind speed influence on NDCT performance and development of methods of performance improvement in windy conditions [1-9]. D. Derksen and T. Bender [3-5] investigated NDCT performance in windy conditions in their experiments in wind tunnel and by numerical simulation. Among the methods of NDCT performance improvement is installation of wind walls in the rain zone and wind deflectors in the inlet windows of NDCT [6-8]. The mentioned technical solutions were investigated experimentally $[6,8]$ and by means of CFD tools [7].

Note that experimental study of the innovative designs with the bench scale models is not adequate because of impossibility to satisfy all necessary similarity criterions of the system. Experimentation on real NDCT is very expensive and it is complicated with instability of the ambience meteorological factors. Analytical investigations are limited with simplified and schematic problem statements. State- of- the- art computational experiment let one perform intensive parametric study of NDCT with high reliability and specification of the system [9-12].

Numerous methods for improvement of NDCT performance are discussed in the literature. Among them variation of the sprinkling density, variation of the 
design and height of fill, aerodynamic control of the flow, onset of the big scale vortex inside NDCT [13] etc. It is shown in [11] that flow rotation in the overshower zone intensifies heat and mass transfer in NDCT and shifts condensation zone to periphery of the shell. Technical solutions for rotation onset are discussed in [14]. The paper [15] is dedicated to numerical investigation of influence of wind walls and inlet window deflectors on NDCT performance in conditions of the side wind.

Patent [16] describes technical proposal of a ventilation window creation in the center of fill for the aim of reduction of total aerodynamic resistance of the NDCT, improvement of the rain zone performance, and possible creation of a vortex movement in the central part of a NDCT shell. Experimental date obtained on the bench-scale model confirm bell-type profile of temperature and humidity in the rain zone which substantiates the idea. Basing on the patent, modernization of the Grodno Power Plant-2 was implemented and positive effect obtained. To note, together with the fill ventilation window, inlet window deflectors were installed and this fact makes it impossible to define a specific separate effect of the central window on the NDCT performance.

In this paper investigation of the NDCT equipped with the fill ventilation window as well as with inlet window deflectors was performed numerically. 3D modeling with standard CFD tools [17] was tested and verified in previous works by the author. Total gas mass flow rate $G$ was calculated as a function of the wind speed for different diameters of the fill ventilation window. The performance efficiency parameter $\eta$, directly defined via NDCT input and output temperatures $T_{\text {wi }}, T_{\text {wo }}$ and "wet bulb" temperature was also estimated. Simulation results are discussed. The obtained data may be utilised for optimization of working NDCTs and construction of new ones.

\section{Problem statement}

The counter flow natural draft wet cooling tower of Woo-Jin Power Plant, Shanghai, China was selected as a prototype of the simulated system. Its height is $150 \mathrm{~m}$, basement diameter is $114 \mathrm{~m}$ and inlet window height $-10 \mathrm{~m}$. Computational domain was a cylinder with the radius and height equal to $500 \mathrm{~m}$ (Fig. 2). The domain consisted of 1.8 million structured and unstructured (hybrid) mesh elements. The mesh size was enough for reliable convergence of iterations and it was kept constant for all cases under investigation. The mesh element size was smoothly stretched from NDCT walls to periphery to resolve the high gradient regions.

We considered NDCT equipped with deflectors in inlet windows and ventilation window in fill (Fig 3). Diameter of the ventilation window was varied $D_{0}=2,4,8$ и $12 \mathrm{~m}$. Inlet windows deflectors were set at an angle of $\alpha=72^{\circ}$ to tangent line, according to recommendations [18]. A standard NDCT not equipped with the mentioned elements (Fig. 3b) was simulated as a reference case. 


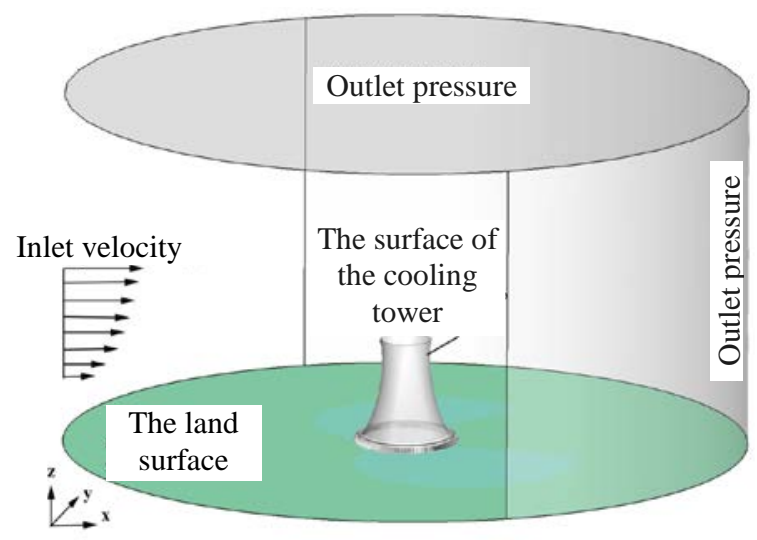

Fig. 2. Computational domain and boundary conditions
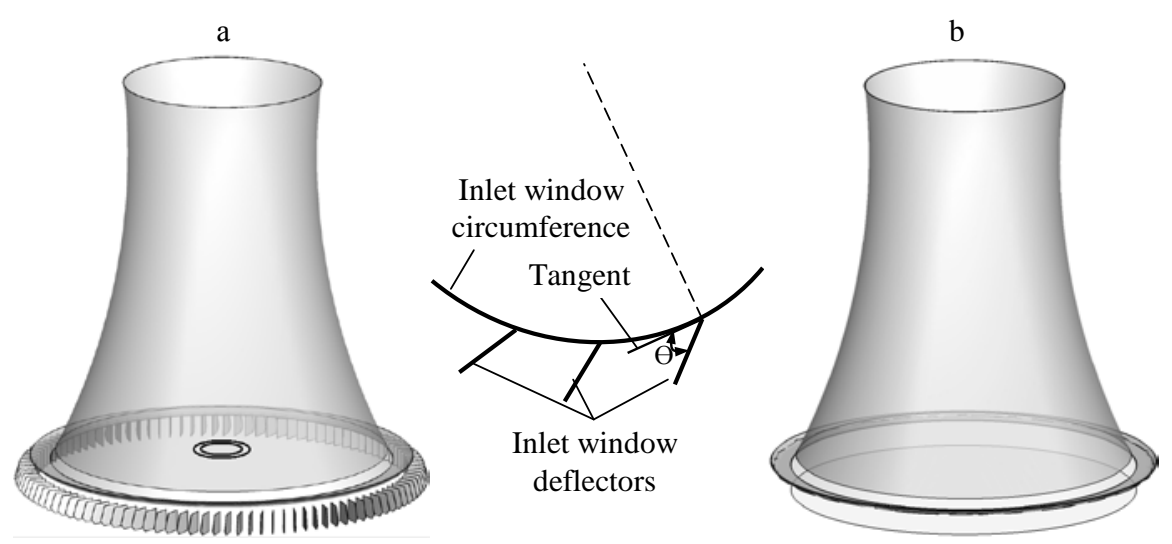

Fig. 3. Scheme of NDCT equiped with deflectors in inlet windows and ventilation window in fill (a) and a standard NDCT (b)

The wind speed vertical distribution was simulated according to the formula [19]

$$
\frac{U_{C W}}{U_{r e f}}=\left(\frac{Z}{Z_{r e f}}\right)^{0.2} .
$$

The reference value of velocity $U_{\text {ref }}$ corresponds to the velocity at the height of $10 \mathrm{~m}$ over the land [19]. It is used as an independent parameter for graphs. Simulations were performed for the $U_{\text {ref }}$ values laying in the range from 0 to $12 \mathrm{~m} / \mathrm{s}$.

The fill of the NDCT together with complimenting elements such as shell supports, spray piping network, fill supports and drift eliminators was simulated by using the Fluent ${ }^{(\mathrm{R})}$ model of "Radiator". The temperature assigned to the "radiator" was fixed. The radiator is characterized with two fundamental parame- 
ters, - pressure loss coefficient $k_{f}$ and heat transfer coefficient $h_{t h}$. The pressure gap on "radiator" was expressed in terms of the pressure loss coefficient, air density, and perpendicular velocity component across the surface [20]

$$
\Delta p=k_{f} \frac{1}{2} \rho v^{2} .
$$

The effective pressure loss coefficients of the tower shell supports, the spray piping network, the fill supports, and the drift eliminators were set to $k_{t s h}=0.5$, $k_{s p n}=0.5, k_{f s}=0.5, k_{d e}=3.0$ correspondingly, according to D. Kröger [21]. The total pressure loss coefficient was obtained as a sum of the particular coefficients $k_{f}=k_{t s h}+k_{s p n}+k_{f s}+k_{d e}=4.5$. The value of the heat transfer coefficient for the "radiator" was defined by tuning of $h_{t h}$ to the experimentally measured value of the total air mass flow rate in [22].

The rain zone of NDCT was simulated as s highly porous media by Fluent ${ }^{(\mathrm{R})}$ tools. The porosity value was determined according to estimated volume of droplets in the zone, the average velocity of droplets and total volume of the sprinkled water being known and comprised $m=0.998$ for the standard parameters of the task. The pressure loss in the rain zone was calculated according to internal procedures of the porous media module of Fluent ${ }^{(\mathrm{R})}$.

\section{Mathematical Model}

In accordance with the stated problem, gas flow was simulated within steady-state Eulerian approach [17]. A single-phase flow is considered, standard $k-\varepsilon$-model of turbulence is adopted. The governing equations for the problem are the Navier - Stokes equations for an incompressible viscous fluid flow, continuity and energy conservation equations:

$$
\begin{gathered}
\frac{\partial \rho}{\partial t}+\nabla(\rho \mathbf{v})=0 \\
\frac{\partial}{\partial t}(\rho \mathbf{v})+\nabla(\rho \mathbf{v v})=-\nabla p+\nabla \bar{\tau}+\rho \mathbf{g} \\
\bar{\tau}=\mu\left[\left(\nabla \mathbf{v}+\nabla \mathbf{v}^{T}\right)-\frac{2}{3} \nabla \mathbf{v I}\right] \\
\frac{\partial(\rho E)}{\partial t}+\nabla(\mathbf{v}(\rho E+p))=0
\end{gathered}
$$

Here $\mathbf{I}$ - unit tensor, the second term in the right hand part of (5) represents volumetric viscosity effect; $E$ - internal energy; $p$ - pressure.

Note that the model doesn't consider latent heat of phase transformations. To take into consideration latent heat of phase transformation we accept hy- 
pothesis of heat and mass transfer equivalence (analogy), formally written in a following form

$$
Q^{t h}+Q^{l a t}=Q^{t o t}=\kappa Q^{t h} .
$$

Here $Q^{\text {th }}$ - convection and conduction heat flow; $Q^{\text {lat }}$ - heat flow defined by phase transformation (evaporation); $\kappa$ - constant coefficient.

The equivalence hypothesis is commonly used in the similar cases if evaporation rate is low (the system is far from boiling parameters). The criterion of applicability of the hypothesis may be written as follows [23]

$$
b=\frac{j_{c i}}{\rho \omega_{0}} \frac{1}{S t_{0}}<0.1,
$$

where $j_{c i}$ - mass flow rate normal to the phase transformation surface; $\rho$ - liquid density; $\omega_{0}$ - gas flow velocity far from surface (out of boundary layer); $S t_{0}$ - Stanton number calculated ignoring mass transfer.

Estimates show that $b \approx 10^{-3}<<0.1$ for the considered case, which justify application of the named hypothesis. The constant parameter in (7) is estimated as $\kappa=2.86$ basing on the data [24].

The influence of the variable humidity on the density of the gaseous flow is neglected. The boundary conditions are applied at the boundaries of the computational domain (Fig. 2) and at solid surfaces of the system. The wind velocity component collinear to wind direction is set according to (1) at the inlet part the boundary.

Air temperature at inlet is set to $T_{\mathrm{a}}=297.15 \mathrm{~K}$. The pressure outlet boundary condition is used to define the air static pressure at the domain outlets (top and right-hand side). In calm conditions $U_{\text {ref }}=0 \mathrm{~m} / \mathrm{s}$ the boundary conditions are defined by pressure.

B.C. at the entrance surface:

$$
\left.v_{x}\right|_{\text {inlet }}=U_{c w} ;\left.\quad v_{y}\right|_{\text {inlet }}=0 ;\left.\quad v_{z}\right|_{\text {inlet }}=0 ;\left.\quad T\right|_{\text {inlet }}=T_{a m b}=297.15 \mathrm{~K} .
$$

At the top surface $(H=500 \mathrm{~m})$ :

$$
\frac{\partial p}{\partial z}=0 ; \quad \frac{\partial v_{x}}{\partial z}=0 ; \quad \frac{\partial v_{y}}{\partial z}=0 ; \quad T=T_{a m b}=297.15 \mathrm{~K} .
$$

At the exit surface of computational domain:

$$
\frac{\partial p}{\partial z}=0 ; \quad \frac{\partial v_{z}}{\partial z}=0 ; \quad T=T_{a m b}=297.5 \mathrm{~K} .
$$

For the solid surfaces (land, NDCT shell, deflectors) no-slip conditions are applied. Described model was used in $[11,15,18]$ and was verified basing on the experimental data on total air flow rate for Minsk Power Plant-4 [25]. 


\section{Results and discussion}

Thermal efficiency of NDCT may be characterized with the value of the total mass flow rate of the cooling air $G$, as far as $G$ is defined by the heat transferred to cooling air. Functional dependence of $G=G\left(Q^{\text {tot }}\right)$ is not linear in general case. Nevertheless parameter $G$ is a suitable parameter for parametric study and comparison of different regimes of NDCT thermal work.

Total mass flow rate of the cooling air was calculated as a function of the wind speed for the cases of ventilation windows radiuses $R=2,4,6,8,10,12 \mathrm{~m}$ and for the case of absence of ventilation window (Fig. 4). Corresponding area of the window related to total area of fill is:

$$
S^{0} / S=1.23 \cdot 10^{-3} ; 4.9 \cdot 10^{-3} ; 1.11 \cdot 10^{-2} ; 1.97 \cdot 10^{-2} ; 3.1 \cdot 10^{-2} \text { and } 4.4 \cdot 10^{-2} .
$$

The case marked as "standard" on the graph corresponds to the simplest (without ventilation window and deflectors) design of the NDCT.

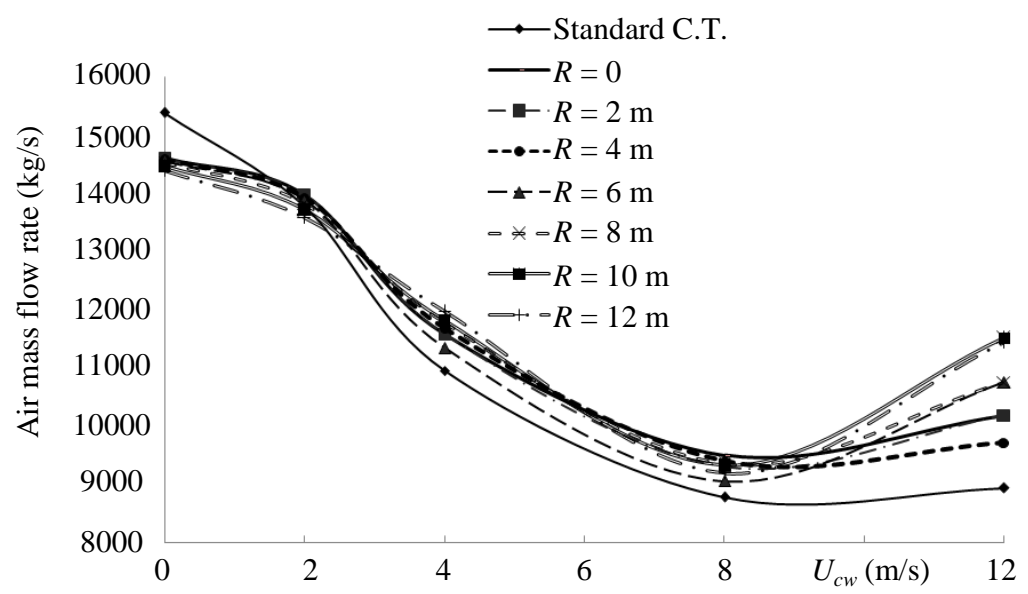

Fig. 4. Total mass flow rate of cooling air $G$ as a function of wind speed $U_{c w}$. Radius of the ventilation window is presented on the graph field. Standard C.T. - standard design of NDCT

Computations show that input window deflectors improve thermal performance of NDCT at any practical wind condition as far as wind calm $U_{c w}<1 \mathrm{~m} / \mathrm{s}$ is very rare case in Belarus. The effect of decrease of the total mass flow rate of cooling air at calm is explained with some aerodynamic resistance of the inlet window defectors. Deflectors provide increase of total mass flow rate of cooling air by approximately $10 \%$ for the typical wind speed, and more in the case of strong air.

Note that the cases with small radius of the ventilation window $(R=2.4 \mathrm{~m})$ are quite similar to the case of absence of window. The differences in the total mass flow rates for the mentioned cases are of the order of computational mistakes and time averaging mistakes. More profound effect of the central window one can observe at stronger wind speed $U_{c w} \sim 10 \mathrm{~m} / \mathrm{s}$ and more. In this condition 
relatively better performance is ensured by bigger windows with area $S^{0} / S \sim 3 \%$ and more.

The commonly used parameter for characterization of NDCT performance is efficiency parameter $\eta$, defined via the temperatures of a water at inlet and outlet of the NDCT $-T_{w i}$ and $T_{w o}$, and the temperature of a wet bulb $T_{w b}$ [24]

$$
\eta=\frac{T_{w i}-T_{w o}}{T_{w i}-T_{w b}}
$$

Parameter $\eta$ characterizes the final aim functionality of cooling tower - temperature reduction of the circulating water taking into consideration physical limitations on performance efficiency connected with ambient air temperature and humidity.

Simulation of the efficiency parameter $\eta$ is presented in the Fig. 5. The temperature of the wet bulb was considered a constant for all computational cases.

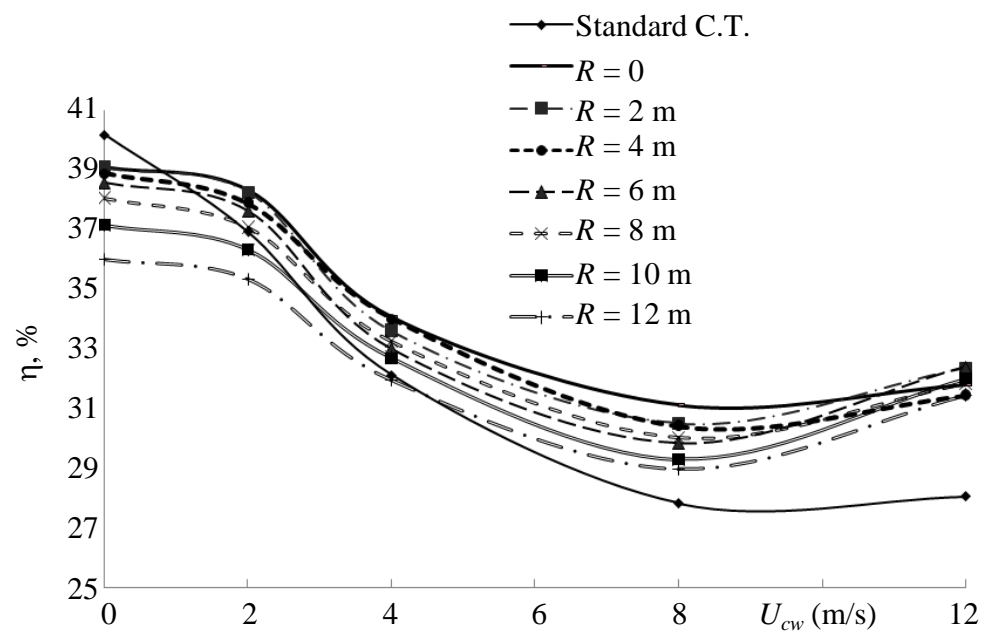

Fig. 5. The efficiency parameter $\eta$ as a function of a cross-wind speed $U_{c w}$. Radius of the ventilation window is presented on the graph field. Standard C.T. - standard design of NDCT

The graphs $\eta\left(U_{c w}\right)$ presented on Fig. 5 let one quantitatively characterize an influence of the ventilation window on the NDCT performance. Computations show that at typical for the central Europe region wind conditions installation of the ventilation window in NDCT fill doesn't improve, but rather impede general thermal performance of NDCT. Situation changes for very strong winds exceeding $12 \mathrm{~m} / \mathrm{s}$.

Note that humidity spatial distribution, which may give some advantage to the fill ventilation window technology, was not considered in the model. Taking into account that 1-2 \% variability of the relative humidity (order of $50 \mathrm{~Pa}$ absolute humidity) may result in only $0.2-0.3 \mathrm{~K}$ variability of the recirculation water, general results and conclusions of the modeling would be generally the same. 


\section{CONCLUSIONS}

Thus, creation of the ventilation windows in fill is not rational for considered in the paper big scale NDCT. The task may be further approached for smaller scale cooling towers and cooling towers operating in conditions of strong cross winds. But for the later case installation of the wind walls, and special inlet window deflectors, NDCT mouth directors etc. should be considered. Creation of the big scale vortex by using oriented sprinkler nozzles [14] also remains one of the perspective technical solution for NDCT performance improvement at average wind velocity conditions.

In view of development of the NDCT simulation program it would be interesting to take into consideration humidity distribution in the system.

\section{Nomenclature}

$G_{a}$ - air mass flow rate, $\mathrm{kg} / \mathrm{s} ; G_{a, 0}$ - mass flow rate of air in windless condition, $\mathrm{kg} / \mathrm{s}$; $g$ - gravity acceleration, $\mathrm{m} / \mathrm{s}^{2} ; H$ - height of inlet window of NDCT, $\mathrm{m} ; j_{c i}-$ mass flow rate normal to interface surface, $\mathrm{kg} / \mathrm{m}^{2} / \mathrm{s} ; \kappa$ - constant parameter; $m$ - porosity; $p$ - pressure, Pa; $Q$ - heat power, $\mathrm{kW}$; $Q^{\text {th }}$ - heat power provided by convective heat transfer, $\mathrm{kW} ; Q^{\text {lat }}$ - latent heat power provided by evaporation of water, $\mathrm{kW} ; S t_{0}-$ Stanton number in the absence of mass transfer; $S$ - total fill area, $\mathrm{m}^{2} ; S^{0}-$ fill ventilation window area, $\mathrm{m}^{2} ; T$ - temperature, $\mathrm{K} ; U_{c . w}$ - cross-wind velocity, $\mathrm{m} / \mathrm{s} ; U_{\text {ref }}$ - wind velocity reference speed for (1), $\mathrm{m} / \mathrm{s} ; U_{c r}-$ critical velocity of cross wind, $\mathrm{m} / \mathrm{s} ; v-$ скорость, $\mathrm{m} / \mathrm{c}$. Greek Symbols: $\mu$ - dynamic viscosity, Pas; $\eta$ - NDCT efficiency parameter; $\rho$ - density, $\mathrm{kg} / \mathrm{m}^{3} ; \omega_{0}$ - stream velocity out of boundary layer, $\mathrm{m} / \mathrm{s}$. Subscripts: ave - average value; $\mathrm{a}$ - air; tot - total or integral value; $\mathrm{i}$ - initial value; $\mathrm{w}$ - water; $\mathrm{o}$ - outlet face value; $\mathrm{cw}$ - cross wind.

\section{REFERENCES}

1. Ming Gao, Feng-Zhong Sun, Kai Wang, Yue-tao Shi, Yuan-bin Zhao (2008) Experimental Research of Heat Transfer Performance on Natural Draft Counter Flow Wet Cooling Tower Under Cross-Wind Conditions. International Journal of Thermal Sciences, 47, 935-941.

2. Caytan Y., Fabre L. (1989) Wind Effects on the Performance of Natural Draft Wet Cooling Towers, Comparison of Constructors Proposals and Realization of Performance Control Tests. International Cooling-Tower Conference. Proceedings, 21 (17), Ref. Number 21068013.

3 Bender T. J., Bergstrom D. J., Rezkallah K. S. (1996) A Study on the Effects of Wind on the Air Intake Flow Rate of a Cooling Tower: Part 3. Wind All Study. Journal of Wind Engineering and Industrial Aerodynamics, 64 (1), 73- 88. DOI: 10.1016/S0167-6105(96)00085-2.

4. Derksen D. D., Bender T. J. (1996) A Study on the Effects of Wind on the Air Intake Flow Rate of a Cooling Tower: Part 1. Wind Tunnel Study. Journal of Wind Engineering and Industrial Aerodynamics, 64 (1), 47-59. DOI: 10.1016/S0167-6105(96)00084-0.

5. Bender T. J., Bergstrom D. J., Rezkallah K. S. (1996) A Study on the Effects of Wind on the Air Intake Flow Rate of a Cooling Tower: Part 2. Wind All Study. Journal of Wind Engineering and Industrial Aerodynamics, 64 (1), 61-72. DOI: 10.1016/S0167-6105(96)00083-9.

6. Madad-Nia J., Koosha H., Mirzaei M. (2008) Effect of Wind Break Walls on Performance of a Cooling Tower Model. Mech. \& Aerospace Eng. Journal, 3 (4), 61-67.

7. Al-Waked R., Behnia M. (2005) The Effect of Windbreak Walls on the Thermal Performance of Natural Draft Dry Cooling Towers. Heat Transfer Engineering, 26 (8), 50-62. DOI: 10. 1080/01457630591003763.

8. Wang K., Sun F. Z., Zhao Y. B., Gao M., Ruan L. (2010) Experimental Research of the Guiding Channels Effect on the Thermal Performance of Wet Cooling Towers Subjected to CrossWinds - Air Guiding Effect on Cooling Tower. Applied Thermal Engineering, 30 (5), 533-538. DOI: 10.1016/j.applthermaleng.2009.10.015. 
9. Al-Waked R. (2010) Cross-Winds Effect on the Performance of Natural Draft Wet Cooling Towers. International Journal of Thermal Sciences, 49 (1), 218-224. DOI: 10. 1016/j.ijther malsci.2009.07.012.

10. Wang K., Sun F. Z., Zhao Y. B., Gao M., Shi Y. T. (2008) Three-Dimensional Regularities of Distribution of Airinlet Characteristic Velocity in Natural-Draft Wet Cooling Tower. Journal of Hydrodynamics, 20 (3), 323-330.

11. Kashani M. M. H., Dobrego K. V. (2013) Heat and Mass Transfer in the Over-Shower Zone of a Cooling Tower with Flow Rotation. Journal of Engineering Physics and Thermophysics, 86 (6), 1490-1499. DOI: 10.1007/s10891-013-0978-9.

12. Al-Waked R., Behnia M. (2006) CFD Simulation of Wet Cooling Towers. Applied Thermal Engineering, 26 (4), 382-395. DOI: 10.1016/j.applthermaleng.2005.06.018.

13. Solodukhin A. D., Dikun V. S., Pavliukevich N. V., Fisenko S. N., Dashkov G. V., Vykhota S. O., Davidenko V. F., Zhdanov V. L., Khomich A. S., Slizhevskii Iu. M., Vlasov A. V., Ganzhin V. A. (1996) Cooling Tower. Patent of Republic of Belarus No 1293. (in Russian).

14. Dobrego K. V., Davydenko V. F., Koznacheyev I. A. (2016) Use of Oriented Spray Nozzles to Set the Vapor-Air Flow in Rotary Motion in the Superspray Space of the Evaporative Chimney-Type Tower. Inzhenerno-fizicheskiy Zhurnal [Journal of Engineering Physics and Thermophysics], 89 (1), 148-157. DOI: 10.1007/s10891-016-1363-2.

15. Kashani M. M. H., Dobrego K. V. (2016) Effect of Inlet Window Deflectors and Windbreak Walls Height on Performance of Natural Draft Cooling Tower under Cross-Wind Condition. Heat Transfer Engineering, 188 (3), 1-9. DOI: 10.1615/HeatTransRes.2016010960 (in print).

16. Vlasov A. V., Davidenko V. F., Dashkov G. V., Martynenko O. G., Rodzevich V. A., Soloduhin A. D., Stolovich N. N., Tjutjuma V. D., Dikun V. S., Hasanevich L. S. (1998) Cooling Tower. Patent of Republic of Belarus No 2447 (in Russian).

17. ANSYS ${ }^{\circledR}$ Academic Research, Release 14.5, Help System, FLUENT, ANSYS, Inc.

19. Panofsky H. A., Dutton J. A. (1984) Atmospheric Turbulence. Models and Methods for Engineering Applications. New York, Wiley Press. 397.

20. Petruchik A., Fisenko S. (2001) Simulation of Natural Draft Cooling Tower Performance. The $12^{\text {th }}$ IAHR Symposium in Cooling Tower and Heat Exchangers. Sydney, Australia, 80-86.

21. Kröger D. G. (2004) Air-Cooled Heat Exchangers and Cooling Towers. Vol. 1. USA, PennWell Books. 502.

22. Vlasov A. V., Dashkov G. V., Solodukhin A. D., Fisenko S. P. (2002) Investigation of the Internal Aerodynamics of the Chimney-Type Evaporative Cooling Tower. InzhenernoFizicheskiy Zhurnal [Journal of Engineering Physics and Thermophysics], 75 (5), 1086-1091 (in Russian).

23. Isachenko V. P., Osipova V. A., Sukomel A. S. (1981) Heat transfer. Moscow, Energoizdat, 292-294 (in Russian).

24. Petruchik A. I., Fisenko S. P. (1999) Mathematical Modeling of Evaporative Cooling of Water Films in Water-Cooling Towers. Inzhenerno-fizicheskiy Zhurnal [Journal of Engineering Physics and Thermophysics], 72 (1), 43-49 (in Russian).

25. Solodukhin A. D., Dashkov G. V. (2011) Research Report No 20113267, A. V. Luikov Heat and Mass Transfer Institute of National Academy of Sciences of Belarus. Minsk (in Russian, Unpublished).

Received: 5 April 2016 Accepted: 3 June 2016 Published online: 26 September 2016

\section{ЛИТЕРАТУРА}

1. Experimental Research of Heat Transfer Performance on Natural Draft Counter Flow Wet Cooling Tower under Cross-Wind Conditions / Ming Gao [et al.] // International Journal of Thermal Sciences. 2008. Vol. 47, No 7. P. 935-941.

2. Caytan, Y. Wind Effects on the Performance of Natural Draft Wet Cooling Towers, Comparison of Constructors Proposals and Realization of Performance Control Tests / Y. Caytan, L. Fabre // International Cooling-Tower Conference. Proceedings. 1989. Vol. 21, No 17. Ref. Number 21068013.

3. Bender, T. J. A Study on the Effects of Wind on the Air Intake Flow Rate of a Cooling Tower: Part 3. Wind All Study / T. J. Bender, D. J. Bergstrom, K. S. Rezkallah // Journal of Wind Engineering and Industrial Aerodynamics. 1996. Vol. 64, No 1. P. 73-88. 
4. Derksen, D. D. A Study on the Effects of Wind on the Air Intake Flow Rate of a Cooling Tower: Part 1. Wind Tunnel Study / D. D. Derksen, T. J. Bender // Journal of Wind Engineering and Industrial Aerodynamics. 1996. Vol. 64, No 1. P. 47-59.

5. Bender, T. J. A Study on the Effects of Wind on the Air Intake Flow Rate of a Cooling Tower: Part 2. Wind All Study / T. J. Bender, D. J. Bergstrom, K. S. Rezkallah // Journal of Wind Engineering and Industrial Aerodynamics. 1996. Vol. 64, No 1. P. 61-72.

6. Madad-Nia, J. Effect of Wind Break Walls on Performance of a Cooling Tower Model J. Madad-Nia, H. Koosha, M. Mirzaei // Mech. \& Aerospace Eng. Journal. 2008. Vol. 3, No 4. P. 61-67.

7. Al-Waked, R. The Effect of Windbreak Walls on the Thermal Performance of Natural Draft Dry Cooling Towers / R. Al-Waked, M. Behnia // Heat Transfer Engineering. 2005. Vol. 26 No 8. P. 50-62.

8. Experimental Research of the Guiding Channels Effect on the Thermal Performance of Wet Cooling Towers Subjected to Cross-Winds - Air Guiding Effect on Cooling Tower / K. Wang [et al.] // Applied Thermal Engineering. 2010. Vol. 30, No 5. P. 533-538.

9. Al-Waked, R. Crosswinds Effect on the Performance of Natural Draft Wet Cooling Towers R. Al-Waked // International Journal of Thermal Science. 2010. Vol. 49, No 1. P. 218-224.

10. Three-Dimensional Regularities of Distribution of Airinlet Characteristic Velocity in NaturalDraft Wet Cooling Tower / K. Wang [et al.] // Journal of Hydrodynamics. 2008. Vol. 20, No 3. P. 323-330.

11. Kashani, M. M. H. Heat and Mass Transfer in the Over-Shower Zone of a Cooling Tower with Flow Rotation / M. M. H. Kashani, K. V. Dobrego // Инженерно-физический журнал. 2013. T. 86, № 6. C. 1490-1499.

12. Al-Waked R. CFD Simulation of Wet Cooling Towers / R. Al-Waked, M. Behnia // Applied Thermal Engineering. 2006. Vol. 26, Issue 4. P. 382-395.

13. Градирня: пат. 1293 Респ. Беларусь: МПК F28C 1/00 / А. Д. Солодухин, В. С. Дикун, Н. В. Павлюкевич, С. Н. Фисенко, Г. В. Дашков, С. О. Выхота, В. Ф. Давыденко, В. Л. Жданов, А. С. Хомич, Ю. М. Слижевский, А. В. Власов, В. А. Ганжин; дата публ.: 16.09.1996.

14. Добрего, К. В. Использование ориентированных брызгальных сопел для придания вращения паровоздушному потоку в надоросительном простанстве башенной испарительной градирни / К. В. Добрего, В. Ф. Давыденко, И. А. Козначеев // Инженерно физический журнал. 2016. Т. 89, № 1. С. 148-157.

15. Kashani, M. M. H. Effect of Inlet Windows Deflectors and Windbreak Walls Height on Performance of Natural Draft Cooling Tower under Cross-Wind Condition / M. M. H. Kashani, K. V. Dobrego // Heat Transfer Engineering. 2016. Vol. 188, No 3. P. 1-9.

16. Градирня: пат. Респ. Беларусь 2447: МПК F28C 1/00 / А. В. Власов, В. Ф. Давыденко, Г. В. Дашков, О. Г. Мартыненко, В. А. Родзевич, А. Д. Солодухин, Н. Н. Столович, В. Д. Тютюма, В. С. Дикун, Л. С. Хасаневич; дата публ. 30.12.1998.

17. ANSYS ${ }^{\circledR}$ Academic Research, Release 14.5, Help System, FLUENT, ANSYS, Inc.

19. Panofsky, H. A. Atmospheric Turbulence. Models and Methods for Engineering Applications / H. A Panofsky, J. A. Dutton. New York: Wiley Press, 1984. 397 p.

20. Petruchik, A. Simulation of Natural Draft Cooling Tower Performance / A. Petruchik, S. Fisenko // The $12^{\text {th }}$ IAHR Symposium in Cooling Tower and Heat Exchangers. Sydney, Australia, 2001. P. 80-86.

21. Kröger, D. G. Air-Cooled Heat Exchangers and Cooling Towers. Vol. 1 / D. G. Kröger. USA PennWell Books, 2004. 502 p.

22. Исследование внутренней аэродинамики башенной испарительной градирни / А. В. Власов [и др.] // Инженерно физический журнал. 2002. Т. 75, № 5. С. 1086-1091.

23. Исаченко, В. П. Теплопередача / В. П. Исаченко, В. А. Осипова, А. С. Сукомел. М. Энергоиздат, 1981. С. 292-294.

24. Петручик, А. И. Математическое моделирование испарительного охлаждения пленок воды в градирнях / А. И. Петручик, С. П. Фисенко // Инженерно-физический журнал. 1999. Т. 72, № 1. С. 43-49.

25. Отчет о НИР № 20113267 / А. Д. Солодухин Г. В. Дашков; Институт тепло- и массообмена имени А. В. Лыкова НАН Беларуси, Минск, 2011.

Поступила 05.04.2016 Подписана в печать 03.06.2016 Опубликована онлайн 26.09.2016 